\title{
Mitigation Scenario for Reducing Greenhouse Gas Emission from Rice Field by Water Management and Rice Cultivars
}

\author{
Ali Pramono, Terry Ayu Adriany and Helena Lina Susilawati \\ Indonesian Agricultural Environment Research Institute (IAERI), Jln Raya Jakenan-Jaken Km 5 Pati, Central \\ Java Province, Indonesia, e-mail: ali_pramono@yahoo.com
}

Received December 06, 2019; Revised March 18, 2020; Accepted 23 March 2020

\begin{abstract}
Rice production is a significant anthropogenic source of methane $\left(\mathrm{CH}_{4}\right)$ and nitrous oxide $\left(\mathrm{N}_{2} \mathrm{O}\right)$, two important greenhouse gases (GHGs). Several strategies for reducing GHGs emissions from paddy fields are water management and the use of low emission rice cultivars. The purpose of this study was to determine the effects of water management and rice cultivars on the grain yield and greenhouse gas (GHG) emissions. The research was conducted at the Indonesian Agricultural Environment Research Institute (IAERI), Pati District, Central Java Province during the dry season 2017 (March-June 2017). The study used a factorial randomized block design with the first factor were water managements: $\mathrm{A}_{1}=$ continuous flooding at $5 \mathrm{~cm}$ height and $\mathrm{A}_{2}=$ alternate wetting and drying/ AWD), and the second factor were rice cultivars: $V_{1}=$ Ciherang, $V_{2}=$ Inpari 32, $V_{3}=$ Mekongga with three replications. All treatments received an equal amount of farmyard manure and inorganic fertilizers. GHG measurements were done by using a closed chamber method. The results of this study indicated that the combination of AWD treatment with Ciherang, Inpari 32, and Mekongga rice cultivars significantly reduced $\mathrm{CH}_{4}$ emissions by $23 \%, 46 \%$, and $6 \%$, respectively. The Inpari 32 rice variety produced the highest grain yield compared to others, but there were no significant differences in grain yield between all of the treatments. Therefore, AWD technique in combination with Inpari 32 rice cultivar could be a potential option for maintaining the yield-scaled global warming potential of rice production at a lower level, without reducing grain yield.
\end{abstract}

Keywords: Alternate wetting and drying, GHG emissions, and rice cultivars

\begin{abstract}
ABSTRAK
Budidaya padi merupakan salah satu sumber emisi gas rumah kaca (GRK) antropogenik metana $\left(\mathrm{CH}_{4}\right)$ dan dinitrogen oksida $\left(\mathrm{N}_{2} \mathrm{O}\right)$. Beberapa strategi untuk mengurangi emisi GRK dari lahan sawah antara lain melalui pengelolaan air dan penggunaan varietas padi yang dapat mengurangi emisi GRK pada level paling rendah. Tujuan penelitian adalah untuk mengetahui pengaruh pengelolaan air dan varietas padi terhadap hasil dan emisi GRK. Penelitian dilakukan di Balai Penelitian Lingkungan Pertanian (Balingtan), Pati-Jawa Tengah pada musim kemarau tahun 2017. Percobaan menggunakan rancangan acak kelompok lengkap factorial dengan faktor pertama adalah pengelolaan air $\left(\mathrm{A}_{1}=\right.$ tergenang secara terus menerus $5 \mathrm{~cm}$ dan $\mathrm{A}_{2}=$ alternate wetting and drying / AWD / pengairan basah-kering), dan faktor kedua adalah varietas padi $\left(\mathrm{V}_{1}=\right.$ Ciherang, $\mathrm{V}_{2}=$ Inpari 32, $\mathrm{V}_{3}=$ Mekongga), masing-masing perlakuan terdiri dari 3 ulangan. Semua plot diberikan takaran pupuk organik dan anorganik yang sama. Pengukuran emisi GRK dilakukan dengan menggunakan metode sungkup tertutup. Hasil penelitian ini menunjukkan bahwa kombinasi perlakuan AWD dengan varietas Ciherang, Inpari 32 dan Mekongga signifikan menurunkan emisi $\mathrm{CH}_{4}$ masingmasing sebesar 23\%, 46\% dan 6\%. Padi Inpari 32 menghasilkan gabah tertinggi dibandingkan varietas yang lain. Teknik AWD yang dikombinasikan penggunaan varietas Inpari 32 merupakan opsi yang berpotensi menurunkan emisi GRK tanpa menurunkan hasil gabah.
\end{abstract}

Kata Kunci: Emisi gas rumah kaca, perlakuan basah-kering, varietas padi 


\section{INTRODUCTION}

Rice is one of the most main food in Asian countries, particularly in Indonesia. Rice requires a lot of water in its cultivation. Climate change has reduced the availability of irrigation water, thus threatening the sustainability of rice production systems. Rice field is one of the sources of greenhouse gas emissions such as methane $\left(\mathrm{CH}_{4}\right)$ and nitrous oxide $\left(\mathrm{N}_{2} \mathrm{O}\right)$ thus contributes to global warming and other negative effects in the agricultural sector (Majumdar 2003; IPCC 2014). One of the strategies to mitigate greenhouse gas emissions from the rice field is water management as well as alternate wetting and drying techniques (AWD). AWD is a water management technique in which the fields are drained and re-flooded one or more times during the growing season. It has been promoted as a strategy to decrease irrigation water use and reduce GHG emissions from rice cultivation while maintaining or improving yields (Richards and Sander 2014). Many studies have shown that AWD reduced water use by more than $30 \%$, without decreasing yield. The $15 \mathrm{~cm}$ AWD treatment is a safe irrigation technique to reduce GHG emissions without reducing grain yield (Setyanto et al. 2018). AWD treatments significantly reduced GHG emissions and grain total of As heavy metal with no reduction in grain yield. Milled grain total As, which averaged $0.114 \mathrm{mg} \mathrm{kg}^{-1}$ in the control, was reduced by $59-65 \%$ by the AWD treatments (La Hue et al. 2016).

The mitigation techniques have been done to reduce the emissions of these two gases, but simultaneous GHG mitigation has not been studied. $\mathrm{CH}_{4}$ mitigation may increase $\mathrm{N}_{2} \mathrm{O}$ emissions and vice versa. The mitigation strategy must be effective, widely applicable, technically feasible, economical, fast, environmentally friendly, and socially acceptable.

Rice plant roles in three key functions related with $\mathrm{CH}_{4}$ production: (1) as a source of the methanogenic substrate, (2) as a conduit for $\mathrm{CH}_{4}$ through a well developed inter-cellular air spaces (aerenchyma), and (3) as active $\mathrm{CH}_{4}$-oxidizing site in the rice rhizosphere by supporting $\mathrm{O}_{2}$ counter transport through the aerenchyma system. Several studies showed that $\mathrm{CH}_{4}$ emitted from rice field to the atmosphere is transported mostly $(60-90 \%)$ through the aerenchyma of the rice plants rather than molecular diffusion across water-air interfaces or release of gas bubbles (Aulakh et al. 2000). The variability of rice cultivars with different growth phases could affect GHG emitted from the soil- atmosphere system. Therefore, rice cultivar selection with low $\mathrm{CH}_{4}$ emission and high yield was very needed to mitigate $\mathrm{GHG}$ emission from the rice field. The purpose of this study was to determine the effect of water management systems and rice varieties on rice yield and GHG emissions.

\section{MATERIALS AND METHODS}

\section{Study Site}

The research was conducted in the experiment field of the Indonesian Agricultural Environment Research Institute, Pati District, Central Java Province from March to June 2017. The soil in the study sites was classified as Aeric Endoaquepts.

\section{Experimental Setup}

The experiment was designed using a $2 \times 3$ factorial randomized block design with the first factor was water managements $(\mathrm{A} 1=$ Continuous flooding at $5 \mathrm{~cm}$ and A2 = Alternate Wetting and Drying / AWD), and the second factor was rice varieties (V1 = Ciherang, V2 = Inpari 32, V3 = Mekongga), with triplicates using a plot size of a $5 \mathrm{~m} \times 6 \mathrm{~m}$ each. The experimental field consisted of 6 treatments and 3 replications. These popular modern varieties in Indonesia were cultivated in areas differing in physiographical characteristics.

All treatments received the similar dosages of farmyard manures (FYM) and chemical fertilizers. The FYM with a dose of $3 \mathrm{Mg} \mathrm{ha}^{-1}$ was given during the soil preparation. Chemical fertilizers consisted of $\mathrm{P}$ (SP 36) $90 \mathrm{~kg} \mathrm{P}_{2} \mathrm{O}_{5} \mathrm{ha}^{-1}, \mathrm{~N}$ fertilizer (Urea) $120 \mathrm{~kg}$ $\mathrm{N} \mathrm{ha}^{-1}$, and $\mathrm{K}$ fertilizer $(\mathrm{KCl}) 90 \mathrm{~kg} \mathrm{~K}_{2} \mathrm{O} \mathrm{ha}^{-1}$. $\mathrm{P}$ fertilization was utilised during the soil tillage as a basalt fertilizer. The first fertilization was in the form of $1 / 2 \mathrm{~N}$ and $1 / 2 \mathrm{~K}$ fertilizer, the second and the third fertilization were given based on Leaf Color Chart (LCC), which was adjusted to the plant needs. The observed parameters were fluxes $\mathrm{CH}_{4}$ and $\mathrm{N}_{2} \mathrm{O}$, $\mathrm{pH}$ and $\mathrm{Eh}$ of the soil, the plant height and the number of tillers, and the grain yield.

\section{$\mathrm{CH}_{4}$ Measurement}

Gas sampling was done weekly by a closed chamber method by using a $50 \mathrm{~cm} \times 50 \mathrm{~cm} \times 100$ $\mathrm{cm}$ chamber size for $\mathrm{CH}_{4}$ measurement, and a 20 $\mathrm{cm} \times 40 \mathrm{~cm} \times 30 \mathrm{~cm}$ for $\mathrm{N}_{2} \mathrm{O} . \mathrm{CH}_{4}$ and $\mathrm{N}_{2} \mathrm{O}$ concentrations in the samples were analyzed by using a gas chromatograph equipped FID (Flame Ionization Detector) and ECD (Electron Capture Detector). Four hills of rice plants were covered 
with a chamber. A rubber stopper, which was pierced with a glass tube and plugged with a septum, was attached at the ceiling of the chamber for collecting the gas samples. The gas samples were taken five times at $5 \mathrm{~min}$ intervals for $\mathrm{CH}_{4}$ and $10 \mathrm{~min}$ for $\mathrm{N}_{2} \mathrm{O}$ gasses by introducing the inside air into an evacuated $10 \mathrm{~mL}$ glass tube through the septum using a double-ended hypodermic needle. The measurement was replicated with 3 chambers in each treatment. Each time, the sampling was conducted between 06:00 AM - 07:00 AM. The rate of flux was calculated based on the change of gas concentration within the chamber's enclosed headspace, with time intervals 0 to $25 \mathrm{~min}$ for $\mathrm{CH}_{4}$ and 0 to 50 min for $\mathrm{N}_{2} \mathrm{O}$ during each sampling. The flux rate at the time of chamber closure was determined through the equation described by Minamikawa et al. (2015).

$$
E=\frac{\mathrm{dc}}{\mathrm{dt}} \times \frac{\mathrm{Vch}}{\mathrm{Ach}} \times \text { p } x \frac{273.2}{273.2+\mathrm{T}}
$$

where :

E : flux of $\mathrm{CH}_{4}$ or $\mathrm{N}_{2} \mathrm{O}\left(\mathrm{mg} \mathrm{m}^{-2}\right.$ day $\left.^{-1}\right)$

$\mathrm{dc} / \mathrm{dt}$ : the concentration change over time of $\mathrm{CH}_{4}$ or $\mathrm{N}_{2} \mathrm{O}\left(\mathrm{ppm}\right.$ menit $\left.{ }^{-1}\right)$

$\mathrm{Vch} \quad$ : chamber volume $\left(\mathrm{m}^{3}\right)$

Ach : chamber area $\left(\mathrm{m}^{2}\right)$

p : gas density $\left(0.717 \mathrm{~kg} \mathrm{~m}^{-3}\right.$ for $\mathrm{CH}_{4}$ and 1.977 $\mathrm{kg} \mathrm{m} \mathrm{m}^{-3}$ for $\mathrm{N}_{2} \mathrm{O}$ at $0^{\circ} \mathrm{C}$ )

$\mathrm{T} \quad$ :average of temperature during gas sampling $\left({ }^{\circ} \mathrm{C}\right)$

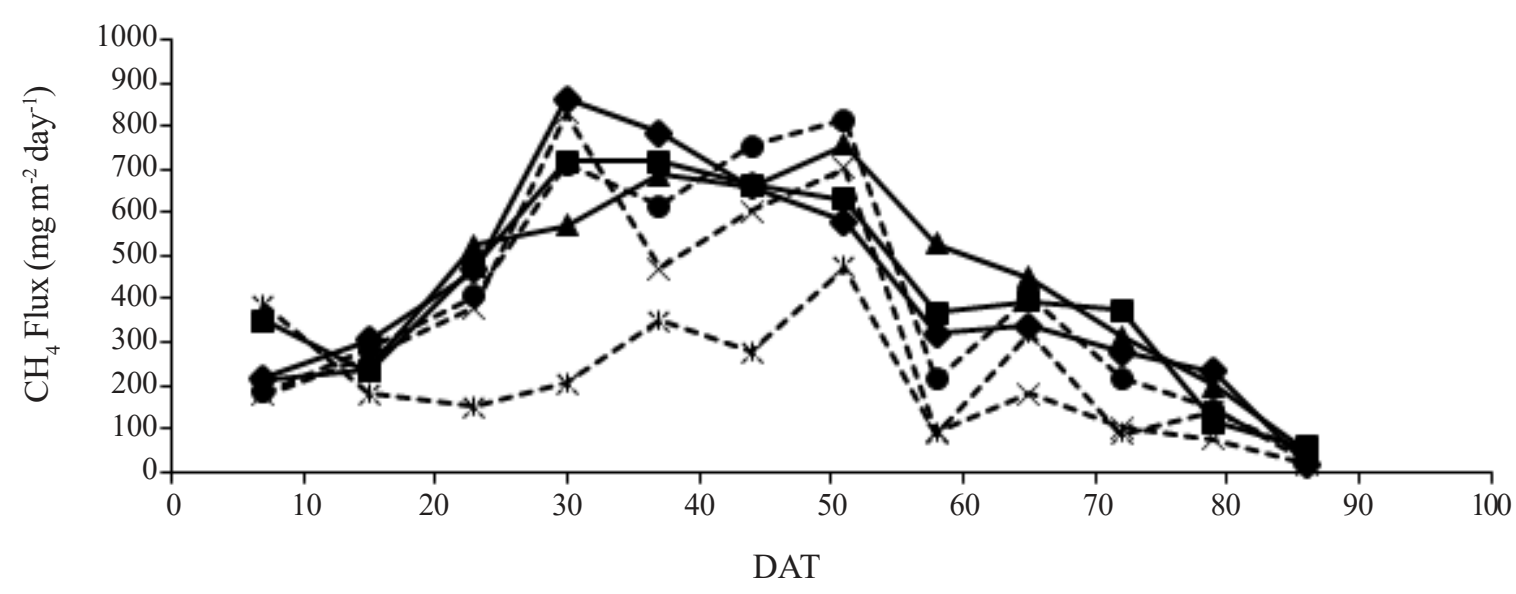

Figure 1. Seasonal variation in $\mathrm{CH}_{4}$ flux under water management and rice varieties. $\mathrm{A} 1=$ Continuous flooding at $5 \mathrm{~cm}, \mathrm{~A} 2=$ Alternate Wetting and Drying $/ \mathrm{AWD}, \mathrm{V} 1=$ Ciherang, $\mathrm{V} 2=$ Inpari 32, V3

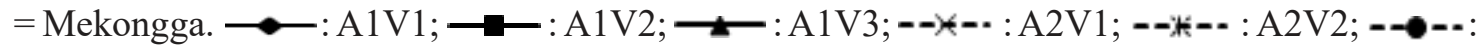
A2V3.

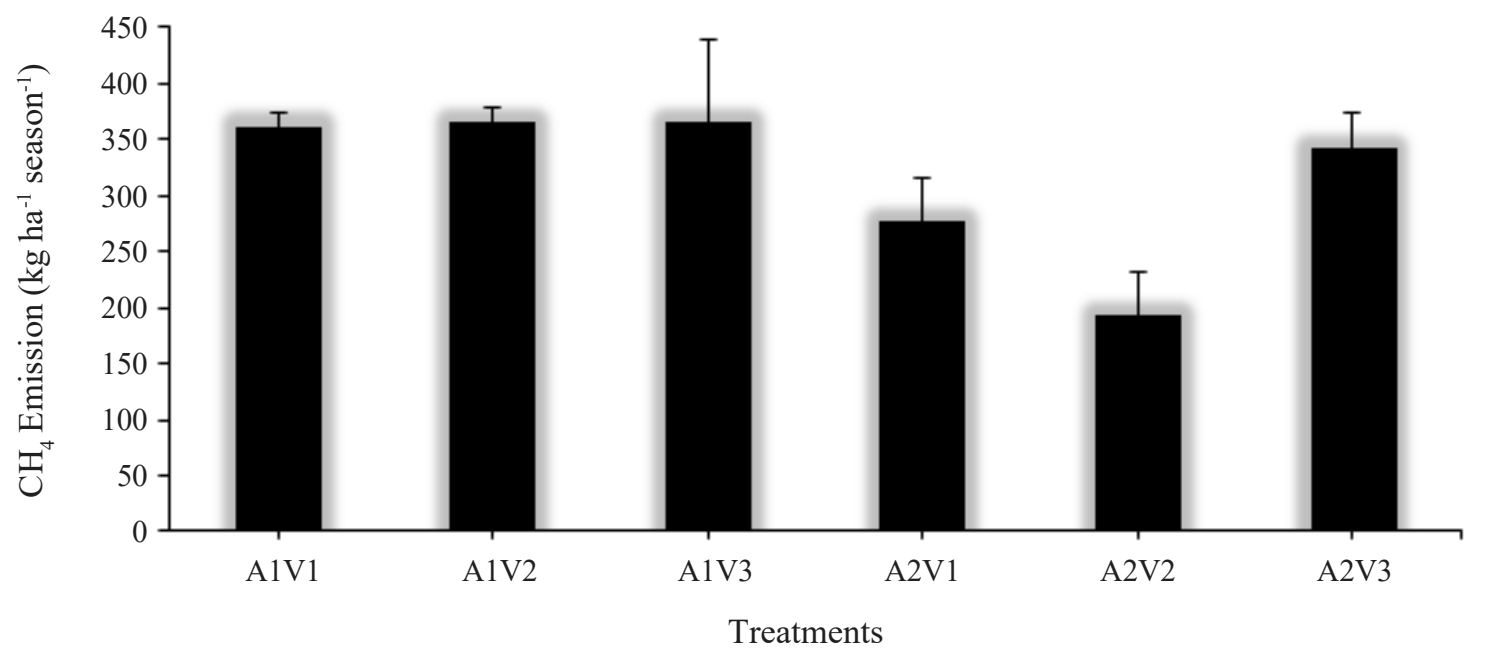

Figure 2. $\mathrm{CH}_{4}$ emission under water management and rice varieties. $\mathrm{A} 1=$ Continuous flooding at $5 \mathrm{~cm}, \mathrm{~A} 2=$ Alternate Wetting and Drying / AWD, V1 = Ciherang, V2 = Inpari 32, V3 = Mekongga. 
Tabel 1. Yield and component under water management and rice varieties.

\begin{tabular}{|c|c|c|c|c|c|c|c|}
\hline Treatments & $\begin{array}{c}\text { Dry weight } \\
\text { of biomass } \\
\text { Mg ha }^{-1}\end{array}$ & $\begin{array}{c}\text { Dry } \\
\text { weight of } \\
\text { root (gr) }\end{array}$ & $\begin{array}{c}\text { Grain } \\
\text { yield } \\
\left(\mathrm{Mg} \mathrm{ha}^{-1}\right)\end{array}$ & $\begin{array}{c}1000 \text { grain } \\
\text { weight } \\
\text { (gr) }\end{array}$ & $\begin{array}{l}\% \text { filled } \\
\text { grain }\end{array}$ & $\begin{array}{l}\text { Grain per } \\
\text { panicle }\end{array}$ & $\begin{array}{l}\text { yield-scaled } \\
\text { GWP }\end{array}$ \\
\hline $\mathrm{A}_{1} \mathrm{~V}_{1}$ & $3.6 \mathrm{c}$ & $2.6 \mathrm{a}$ & $4.0 \mathrm{~b}$ & $26.1 \mathrm{c}$ & $62.9 \mathrm{~b}$ & $877 \mathrm{~b}$ & 0.53 \\
\hline $\mathrm{A}_{1} \mathrm{~V}_{2}$ & $4.9 \mathrm{a}$ & $2.7 \mathrm{a}$ & $5.7 \mathrm{a}$ & $27.4 \mathrm{a}$ & $74.3 \mathrm{a}$ & $1.135 \mathrm{a}$ & 0.54 \\
\hline $\mathrm{A}_{1} \mathrm{~V}_{3}$ & $3.5 \mathrm{c}$ & $3.0 \mathrm{a}$ & $4.0 \mathrm{~b}$ & $24.5 \mathrm{~d}$ & $73.0 \mathrm{ab}$ & $836 \mathrm{~b}$ & 0.53 \\
\hline $\mathrm{A}_{2} \mathrm{~V}_{1}$ & $3.9 b c$ & $2.4 \mathrm{a}$ & $4.4 \mathrm{~b}$ & $26.6 \mathrm{~b}$ & $65.0 \mathrm{ab}$ & $885 b$ & 0.53 \\
\hline $\mathrm{A}_{2} \mathrm{~V}_{2}$ & $4.3 \mathrm{~b}$ & $2.3 \mathrm{a}$ & $5.4 \mathrm{a}$ & $27.7 \mathrm{a}$ & $74.9 \mathrm{a}$ & $1.018 \mathrm{a}$ & 0.56 \\
\hline $\mathrm{A}_{2} \mathrm{~V}_{3}$ & $3.8 \mathrm{bc}$ & $2.7 \mathrm{a}$ & $4.3 \mathrm{~b}$ & $25.3 \mathrm{e}$ & $73.3 \mathrm{ab}$ & $860 \mathrm{~b}$ & 0.53 \\
\hline
\end{tabular}

Different lowercase letter indicate the significant differences $(\mathrm{P}<0.05)$ based on LSD multiple range tests. A1 represents continuous flooding; A2 represents AWD; V1 represents Ciherang; V2 represents Inpari 32 and V3 represents Mekongga.

\section{RESULT AND DISCUSSION}

\section{Greenhouse Gas Flux and Global Warming Potential}

The results showed that the $\mathrm{CH}_{4}$ flux pattern in all treatments generally increased at the beginning of plant growth and increased rapidly in the active tillering phase (Figure 1). The $\mathrm{CH}_{4}$ flux at all treatments reached its peaks in the maximum tillering phase and gradually declined after the maturity phase. The $\mathrm{CH}_{4}$ flux ranged between $86-863 \mathrm{mg}$ $\mathrm{m}^{-2} \mathrm{~min}^{-1}$. The dynamics of the $\mathrm{CH}_{4}$ flux were greatly influenced by the water conditions, in which the formation of $\mathrm{CH}_{4}$ was optimum in continuous flooding. The $\mathrm{CH}_{4}$ emissions from water treatment and rice varieties ranged from $193-367 \mathrm{~kg} \mathrm{ha}^{-1}$. The highest $\mathrm{CH}_{4}$ emission was in $\mathrm{A}_{1} \mathrm{~V}_{3}$ treatment, followed by $A_{1} V_{2}, A_{1} V_{1}, A_{2} V_{3}, A_{2} V_{1}$, and $A_{2} V_{2}$ respectively (Figure 2). In the Ciherang, Inpari 32, and Mekongga varieties, the AWD treatment decreased $\mathrm{CH}_{4}$ emissions by $23 \%, 46 \%$, and $6 \%$, respectively. Interaction between water and rice varieties significantly affected $\mathrm{CH}_{4}$ emissions. Water management influenced rice production and $\mathrm{CH}_{4}$ and $\mathrm{N}_{2} \mathrm{O}$ emissions from rice systems. AWD-15 cm treatment could reduce $\mathrm{CH}_{4}$ emissions by $37.4-45.7 \%$ compared to conventional practices in South China (Liang et al. 2016). Also, AWD treatment was reported to reduce $\mathrm{CH}_{4}$ emissions by 48 to $93 \%$ compared to those observed under continuous flooding systems (Xu et al. 2015; Linquist et al. 2015; Lahue et al. 2016).

All rice varieties have almost similar of growth perioAll rice varieties have almost similar growth period. Differences in $\mathrm{CH}_{4}$ emissions might be caused by different rooting systems. The dry weight of Mekongga rice roots was highest among other varieties (Table 1) so that both in flooded conditions and AWD emitted the highest $\mathrm{CH}_{4}$. The differences of $\mathrm{CH}_{4}$ emissions with different cultivars because of differences in the number of root exudates and degrading roots which influence carbon substrate availability (Wang et al. 1997); tiller numbers, leaf area, and quantity (Gogoi et al. 2008); $\mathrm{CH}_{4}$ production, oxidation, and transport capacity (Ma et al. 2010); grain starch content ( $\mathrm{Su}$ et al. 2015); duration in the field (Badawi and Ghanem 2001) and aerenchyma structure which affects methane transport from the soil to the atmosphere (Wassman et al. 1993). Physiologically, rice plants provide carbon substrate for methanogens, through root exudates, and emit $\mathrm{CH}_{4}$ gas through aerenchyma (Wassman and Aulakh 2000; Zheng et al. 2014). $\mathrm{CH}_{4}$ and $\mathrm{N}_{2} \mathrm{O}$ emissions were positively correlated with root dry weight, leaf area, and number of tillers (Baruah et al. 2010). Rice plant affected $\mathrm{CH}_{4}$ production by influencing soil Eh (Wang et al. 1997) because there were variations in root respiration and organic matter exudation among rice cultivars (Han et al. 2013). The $\mathrm{CH}_{4}$ emitted by plant-mediated transport depends on the aerenchyma system among rice cultivars (Tokida et al. 2013).

Soil redox potential during plant growth in all treatments was strongly influenced by the anaerobic condition. In anaerobic conditions, Eh value tended to decrease, whereas, in aerobic conditions, Eh tended to increase (Figure 3). The results of the Eh measurements during the growing season on all water treatments and varieties showed similar patterns. After 15 days of flooding, Eh decreased to $-120 \mathrm{mV}$ and then stabilized to $72 \mathrm{DAT}$, except in A2V2 treatment (AWD with Inpari 32 varieties) increased at 65 and 72 DAT due to aerobic conditions in the soil. A week before harvest, the soil conditions were dried in all treatments, so Eh increased. Soil $\mathrm{pH}$ observed at all treatments that there was a gradual decrease of acidity during the growing season (Figure 4). This may be caused by 


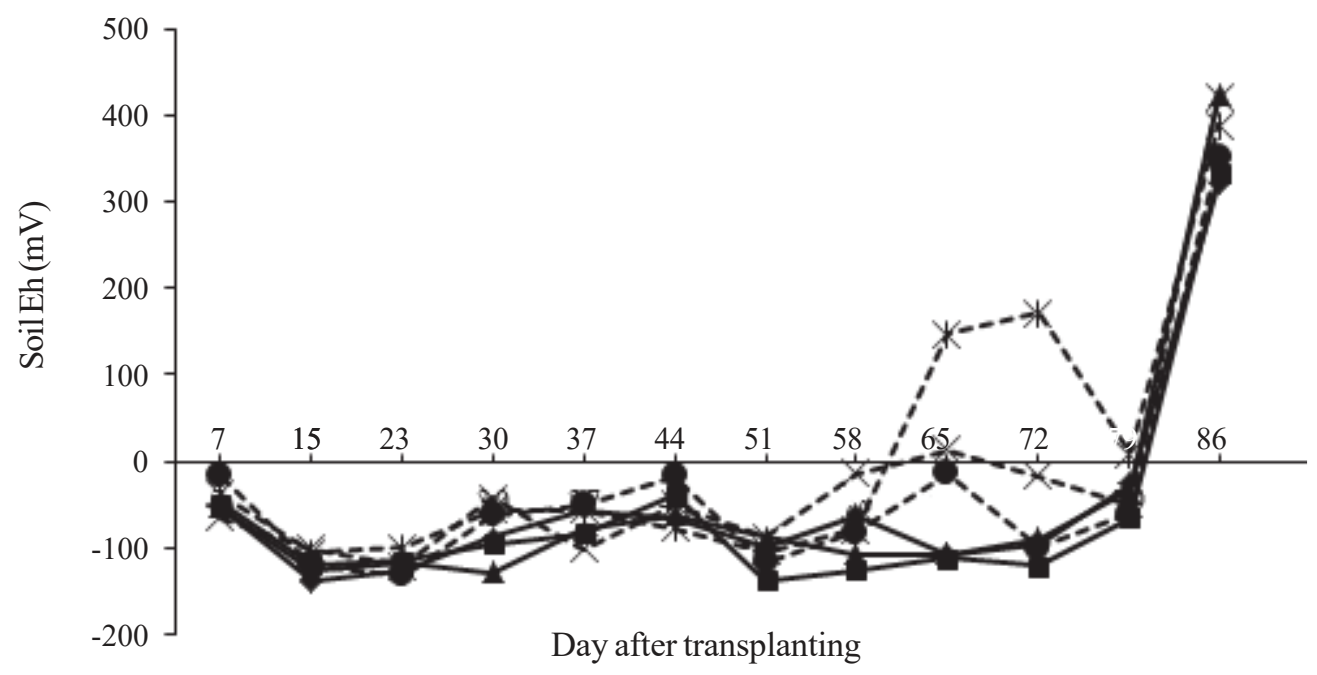

Figure 3. Eh under water management and rice varieties. A1 $=$ Continuous flooding at $5 \mathrm{~cm}, \mathrm{~A} 2=$ Alternate Wetting and Drying / AWD, V1 = Ciherang, V2 = Inpari 32, V3 = Mekongga $\longrightarrow: \mathrm{A} 1 \mathrm{~V} 1$

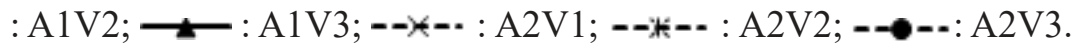

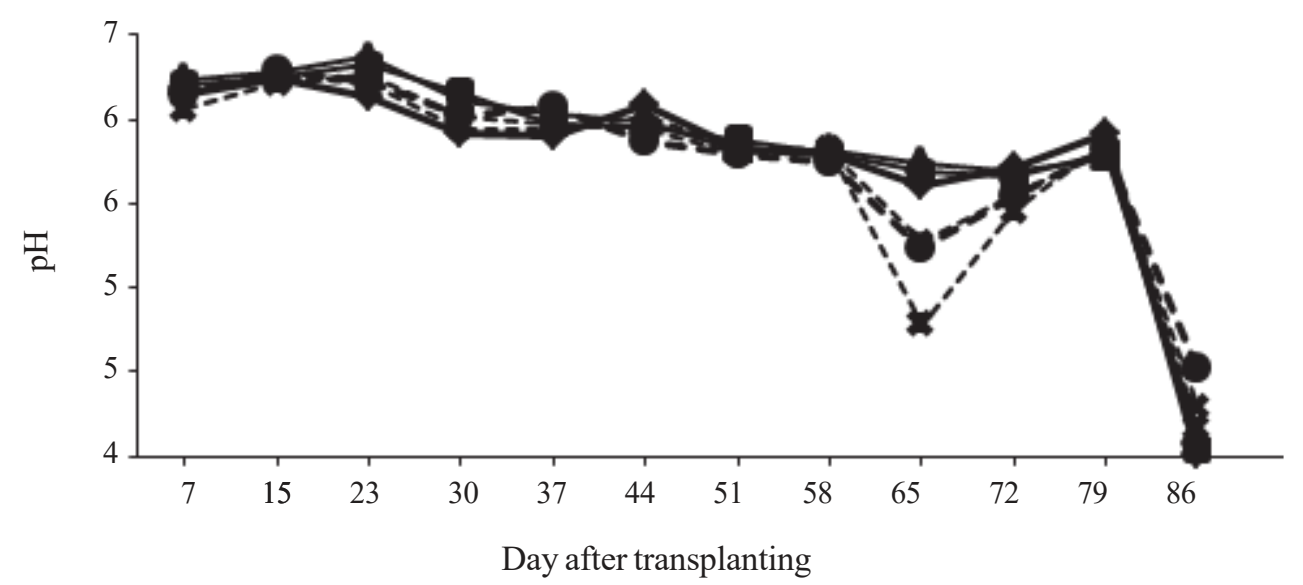

Figure 4. $\mathrm{pH}$ Observation under water management and rice varieties. A1 $=$ Continuous flooding at $5 \mathrm{~cm}, \mathrm{~A} 2$ = Alternate Wetting and Drying $/ \mathrm{AWD}, \mathrm{V} 1$ = Ciherang, V2 = Inpari 32, V3 = Mekongga.——:

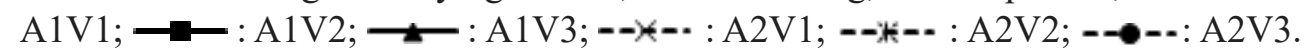

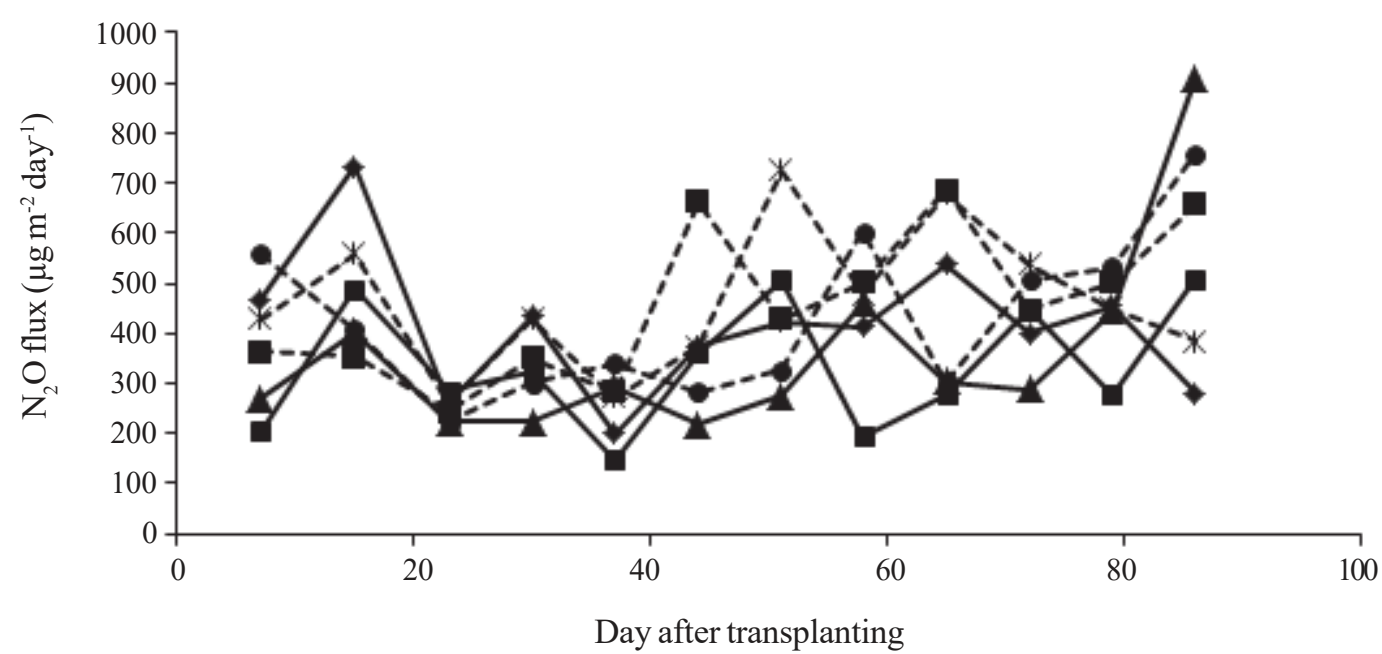

Figure 5. $\mathrm{N}_{2} \mathrm{O}$ flux pattern under water management and rice varieties. $\mathrm{A} 1=$ Continuous flooding at $5 \mathrm{~cm}, \mathrm{~A} 2$ $=$ Alternate Wetting and Drying $/ \mathrm{AWD}, \mathrm{V} 1$ = Ciherang, V2 = Inpari 32, V3 = Mekongga.— :

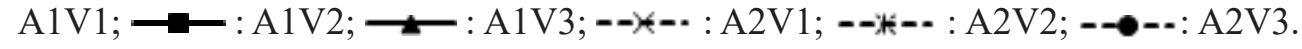




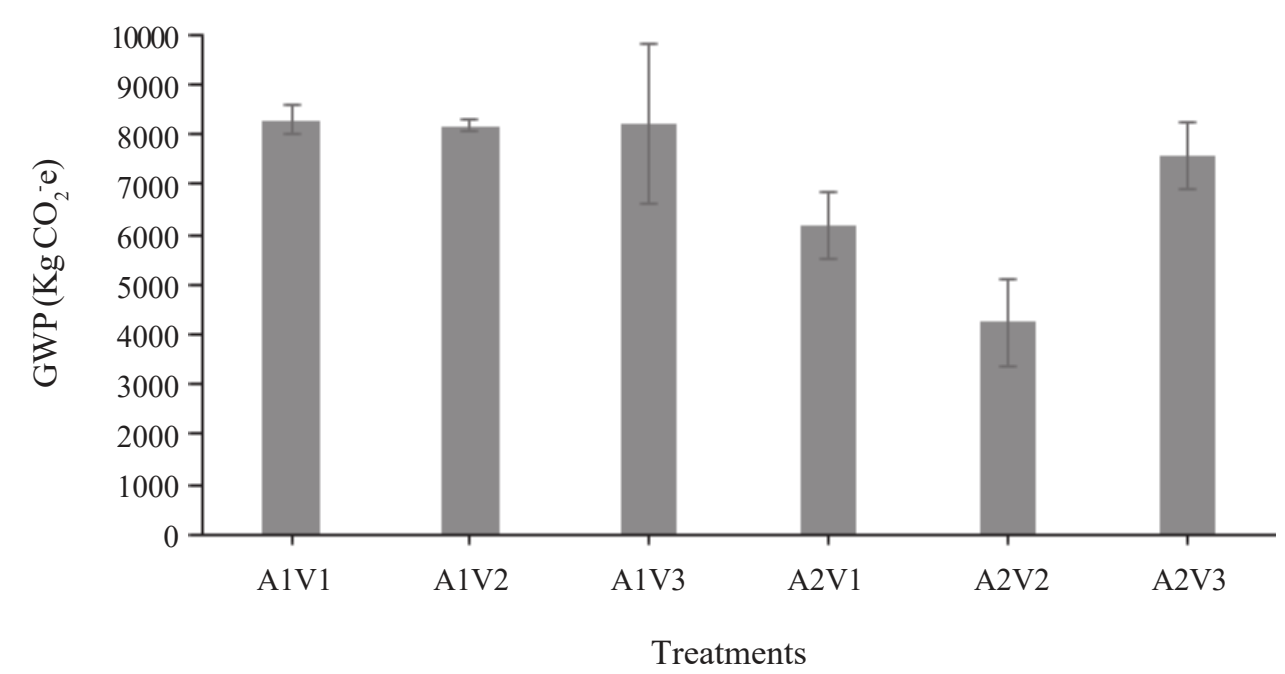

Figure 6. GWP under water management and rice varieties. A1 $=$ Continuous flooding at $5 \mathrm{~cm}, \mathrm{~A} 2=$ Alternate Wetting and Drying / AWD, V1 = Ciherang, V2 = Inpari 32, V3 = Mekongga. ——: A1V1;

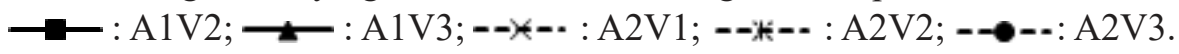

organic acids produced by rice roots. These organic acids are the substrate of methanogen to produce $\mathrm{CH}_{4}$.

Inorganic fertilization affects the $\mathrm{N}_{2} \mathrm{O}$ flux pattern. Mishra et al. (2012) stated that the application of fertilization is closely related to $\mathrm{N}_{2} \mathrm{O}$ emissions. Inorganic fertilization performed on the active tiller phase (7 DAT), the maximum tiller phase (21 HST) and the primordial phase (42 DAT) led to an increase in $\mathrm{N}_{2} \mathrm{O}$ flux (Figure 5). The cumulative flux of $\mathrm{N}_{2} \mathrm{O}$ is shown in Figure 6, the highest cumulative flux was present in the treatment of $A_{1} V_{1}$. The lowest $\mathrm{N}_{2} \mathrm{O}$ flux cumulative was found in $\mathrm{A}_{1} \mathrm{~V}_{2}$ treatment, followed by $A_{1} V_{3}$ and $A_{1} V_{1}$. In the flooded condition, the nitrification and denitrification process was slower so that the formation of $\mathrm{N}_{2} \mathrm{O}$ was low. The highest $\mathrm{N}_{2} \mathrm{O}$ emissions in the $\mathrm{A}_{2} \mathrm{~V}_{2}$ treatment, due to the dry wet period of the AWD treatment, resulted in aerobic and aerobic conditions that were so suitable for nitrification and denitrification. Several studies reported similar $\mathrm{N}_{2} \mathrm{O}$ emissions from soil under either AWD or continuous flooding (Johnson-Beebout et al. 2009; Kim et al. 2014), and trade-offs between $\mathrm{CH}_{4}$ and $\mathrm{N}_{2} \mathrm{O}$ emissions have also been reported (Zou et al. 2005; Kim et al. 2014). To concurrently reduce $\mathrm{CH}_{4}$ and $\mathrm{N}_{2} \mathrm{O}$ emissions, consequently, the GWP of irrigated rice, both water and nitrogen inputs need to be optimized (Johnson-Beebout et al. 2009).

Water treatment and rice varieties gave GWP vary widely, the highest GWP was seen $\mathrm{A}_{1} \mathrm{~V}_{1}$ (Figure 6) accounted for 8.27 tons of $\mathrm{CO}_{2}$-e ha ${ }^{-1}$ season $^{-1}$. The lowest GWP was $\mathrm{A}_{2} \mathrm{~V}_{2}$ treatment (AWD with Inpari 32 variety) which is 4.24 ton ha ${ }^{-1}$ season $^{-1}$. Since $\mathrm{N}_{2} \mathrm{O}$ emissions from all treatments are relatively small, GHG emissions are greatly affected by $\mathrm{CH}_{4}$ emissions. The GWP reduction of AWD treatment combined Ciherang, Inpari 32 and Mekongga varieties were $23 \%, 46 \%$, and $6 \%$, respectively. Inpari 32 rice variety emitted the lowest compared to Ciherang and Mekongga varieties in AWD treatment.

\section{Effect of Water Managements and Rice Cultivars on Rice Yields}

Inpari 32 and Mekongga rice varieties have higher performance and their number of tillers were also higher than Ciherang. The plant height of all rice varieties tested reached $95 \mathrm{~cm}$. The number of tillers of Inpari 32 and Mekongga rice seedlings ranged from 9 to 10 , while Ciherang only had 8-9 of tillers. Despite having the least tillers, Ciherang emitted $\mathrm{CH}_{4}$ higher than Inpari 32 varieties on the AWD treatment. The growth period of all rice varieties used in this study was almost similar to 100 days.

The rice yields from water treatment and varieties are presented in Table 1. The highest grain yield was found in $\mathrm{A}_{1} \mathrm{~V}_{2}$ treatment, which was 5.7 tons $\mathrm{ha}^{-1}$. There was a decrease in yield on AWD treatment with Inpari 32 varieties, which only reached 5.4 ton ha ${ }^{-1}$ or about $5 \%$, but the decrease did not occur on the use of Ciherang and Mekongga varieties. The lowest grain yield was found in $A_{1} V_{3}$ treatment of 3.99 tons ha ${ }^{-1}$. AWD treatment did not consistently decrease results in this study. The smallest of yield-scaled GWP, the ratio of GHGs emission by rice yield from the smallest were $\mathrm{A}_{2} \mathrm{~V}_{2}$, $\mathrm{A}_{1} \mathrm{~V}_{2}, \mathrm{~A}_{2} \mathrm{~V}_{1}, \mathrm{~A}_{2} \mathrm{~V}_{3}, \mathrm{~A}_{1} \mathrm{~V}_{1}, \mathrm{~A}_{1} \mathrm{~V}_{3}$, respectively of 0.92 ; 
$1.61 ; 1.62 ; 2.04 ; 2.27$; and 2.32 . The smaller the yield-scaled GWP means the smaller the emitted GHG to produce rice grain.

Inpari 32 has the highest plant biomass compared to Ciherang and Mekongga. This is also reflected in the highest dry weight of straw per hectare at $\mathrm{A}_{1} \mathrm{~V}_{2}$ treatment ( $\mathrm{CF}$ with Inpari 32 rice variety). However, Inpari 32 root biomass was the lowest among the tested varieties, although it was not significantly different. This may be related to the magnitude of the emitted $\mathrm{CH}_{4}$, so that Inpari 32 has the lowest $\mathrm{CH}_{4}$ emission in the AWD treatment. Root has a significant effect on $\mathrm{CH}_{4}$ emission (Aulakh et al. 2000; Setyanto et al. 2004). The number of grains per panicle, the percentage of grainfilled, and the weight of 1000 grains of rice on Inpari 32 was the highest compared to Ciherang and Mekongga. Inpari 32 rice variety had a high biomass index, this means that photosynthesis was more efficient to produce grain. The results of the present study have shown that $\mathrm{CH}_{4}$ emission from rice fields can be mitigated by proper management of irrigation water and high-yielding rice cultivars with low $\mathrm{CH}_{4}$ emission. This approach is probably the most effective option for mitigating $\mathrm{CH}_{4}$ emission.

\section{CONCLUSSION}

The treatment of AWD technique combined with Ciherang, Inpari 32, and Mekongga rice cultivars significantly decreased $\mathrm{CH}_{4}$ emissions by $23 \%$, $46 \%$, and $6 \%$, respectively. Grain yield was not a significant difference between all of the treatments. Therefore, the AWD technique in combination with Inpari 32 rice cultivar could be a potential option for maintaining the yield-scaled global warming potential of rice production at a lower level without reducing rice yield significantly compared to continuous flooding.

\section{ACKNOWLEDGEMENT}

The authors thanks to Suharsih, Titi Sopiawati, Jumari, Sri Wahyuni, Yono, Suryanto for valuable assistant in the field and Greenhouse Gas Laboratory, IAERI.

\section{REFERENCES}

Aulakh MS, J Bodenbender, R Wassmann and $\mathrm{H}$ Rennenberg. 2000. Methane transport capacity on rice plants. I. Influenced of methane concentration and growth stage analyzed with an automated measuring system. Nutr Cycl Agroecosys 58: 357366.
Badawi AT and SA Ghanem. 2001. Water use efficiency in rice culture. In: J Chataigner (ed). Future of Water Management for Rice in Mediterranean Climate Areas: Proceedings of the Workshops. CIHEAM Options Mediterranian 40, pp. 39-45.

Baruah KK, B Gogoi and P Gogoi. 2010. Plant physiological and soil characteristics associated with methane andnitrous oxide emission from rice paddy. Physiol Mol Biol Plants 16: 79-91. doi: https://doi.org/10.1007/s12298-010-0010-1.

Gogoi N, K Baruah, B Gogoi and PK Gupta. 2008. Methane emission from two different rice ecosystems (Ahu and Sali) at lower Brahmaputra valley zone of North East India. Appl Ecol Environ Res 6: 99-112. doi: 10.15666/aeer/0603_099112.

IPCC [Intergovernmental Panel on Climate Change]. 2014. Mitigation of Climate Change. In: O Edenhofer, R Pichs-Madruga, Y Sokona, E Farahani, S Kadner, K Seyboth, AAdler, I Baum, $\mathrm{S}$ Brunner and $\mathrm{P}$ Eickemeier (eds). Contribution of Working Group III to the Fifth Assessment Report of the Intergovernmental Panel on Climate Change. Cambridge University Press, Cambridge, UK, New York, NY, USA.

Han C, WH Zhong, WS Shen, ZW Cai and B Liu. 2013. Transgenic Bt rice has adverse impacts on $\mathrm{CH}_{4}$ flux and rhizosperic methanogenic archaecal and methanotrophic bacterial communities. Plant Soil 396: 297-316

Johnson-Beebout SE, OR Angeles, MCR Alberto and RJ Buresh. 2009. Simultaneous minimization of nitrous oxide and methane emission from rice paddy soils is improbable due to redox potential changes with depth in a greenhouse experiment without plants. Geoderma 149: 45-53.

Kim GY, J Gutierrez, HC Jeong, JS Lee, MDM Haque and JP Kim. 2014. Effect of intermittent drainage on methane and nitrous oxide emissions under different fertilization in a temperate paddy soil during rice cultivation. J Korean Soc Appl Biol Chem 57: 229236.

LaHue GT, RL Chaney, MAA Adviento-Borbe and BA Linquist. 2016. Alternate wetting and drying in high yielding direct-seeded rice systems accomplished multiple environmental and agronomic objectives. Agric Ecosyst Environ 229: 30-39. http://dx.doi.org/ 10.1016/j.agee.2016.05.020.

Liang K, X Zhong, N Huang, RB Lampayan, J Pan, K Tian and Y Liu. 2016. Grain yield, water productivity and $\mathrm{CH} 4$ emission on irrigated rice in response to water management in south China. Agric. Water Manage 163:319-331.

Linquist BA, MM Anders, MAA Adviento-Borbe, RL Chaney, LL Nalley, EFF da Rosa and C van Kessel. 2015. Reducing greenhouse gas emissions, water use, and grain arsenic levels in rice systems. Glob Chang Biol 21: 407-417.

Ma K, QF Qiu and YH Liu. 2010. Microbial mechanism for rice variety control on methane emission from rice field soil. Global Chang Biol 16: 3085-3095. 
Majumdar D. 2003. Methane and nitrous oxide emission from irrigated rice fields: Proposed mitigation strategies. Curr Sci 84: 1317-1326.

Richards M and BO Sander. 2014. Alternate Wetting and Drying in Irrigated Rice:Implementation Guidance for Policymakers and Investors. Internet Resource. (https://cgspace.cgiar.org/bitstream/handle/10568/ 35402/infonote_CCAFS_AWD_final_A4.pdf).

Setyanto P, AB Rosenani, R Boer, CI Fauziah and MJ Khanif. 2004. The effect of rice cultivar on methane emission from irrigated rice field. Indones J Agric Sci 5: 20-31.

Setyanto P, A Pramono, TA Adriany, HL Susilawati, T Tokida, AT Padre and K Minamikawa. 2018. Alternate wetting and drying reduces methane emission from a rice paddy in Central Java, Indonesia without yield loss. Soil Sci Plant Nutr 64: 23-30. doi: 10.1080/00380768.2017.1409600.

Su J, C Hu, X Yan, Y Jin, Z Chen, Q Guan, Y Wang, D Zhong, C Jansson and F Wang. 2015. Expression of barley SUSIBA2 transcription factor yields highstarch low-methane rice. Nature 523: 602-606.

Wang B, HU Neue and HP Samonte. 1997. Effect of cultivar difference ('IR72', 'IR65598' and 'Dular') on methane emission. Agric Ecosyst Environ 62: 31-40.
Wassman R and MS Aulakh MS. 2000. The role of rice plants in regulating mechanisms of methane missions. Biol Fertil Soils 31: 20-29.

Wassman R, H Schütz, H Papen, H Rennenberg, S Wolfgang, D Aiguo, S Renxing, S Xingjian and W Mingxing W. 1993. Quantification of methane emissions from Chinese rice fields (Zhejiang Province) as influenced by fertilizer treatment. Biogeochemistry 11: 83-101.

Xu Y, J Ge, S Tian, S Li, AL Nguy-Robertson, M Zhan and C Cao. 2015. Effects of water-saving irrigation practices and drought resistant rice variety on greenhouse gas emissions from a no-till paddy in the central lowlands of China. Sci Total Environ 505: 1043-1052.

Zheng H, H Huang, L Yao, J Liu, H He and J Tang. 2014. Impacts of rice varieties and management on yieldscaled greenhouse gas emissions from rice fields in China: A meta-analysis. Biogeosciences 11:3685-3693.

Zou J, Y Huang, J Jiang, X Zheng and RL Sass. 2005. A 3year field measurement of methane and nitrous oxide emissions from rice paddies in China: Effects of water regime, crop residue, and fertilizer application. Glob Biogeochem Cy 19, GB2021. doi:10.1029/ 2004GB002401 